\title{
The Vipassana of Phrassong Saiphra Ajarn Man Phurithatto
}

\author{
Chakard Wanapaiboon ${ }^{1}$, Songkoon Chantachon ${ }^{1} \&$ Somchai Wanlu ${ }^{2}$ \\ ${ }^{1}$ The Faculty of Cultural Science, Mahasarakham University, Khamriang Sub-District, Kantarawichai District, \\ Maha Sarakham Province, Thailand \\ ${ }^{2}$ Khon Kaen Court of Appeals, Nasunratchagarn Road, Mueang District, Khon Kaen Province, 40000, Thailand \\ Correspondence: Chakard Wanapaiboon, The Faculty of Cultural Science, Mahasarakham University, \\ Khamriang Sub-District, Kantarawichai District, Maha Sarakham Province 44150, Thailand. E-mail: \\ cwanapaibol151@gmail.com
}

Received: May 30, 2014 Accepted: June 13, 2014 Online Published: June 12, 2014

doi:10.5539/ach.v6n2p171 URL: http://dx.doi.org/10.5539/ach.v6n2p171

\begin{abstract}
The most influential student of Phra Ajarn Sao Kantasilo Mahathera was Phrassong Saiphra Ajarn Man Phurithatto. Ajarn Man, as he was commonly known, focused on the vipassana field and spent his time meditating in forests and caves. This paper analyses the Thai forest tradition of Phrassong Saiphra Ajarn Man Phurithatto with a focus on vipassana, or meditation. The article details the doctrine of Ajarn Man and his philosophy of meditation. Eleven requisite characteristics are identified for a suitable monk in the mould of Ajarn Man and three obstacles to the preservation of vipassana are discussed: decline of natural environment, weak mentality in the clergy and poor administration. The research concludes these three obstacles may be overcome with a greater sense of role and responsibility from related government institutions.
\end{abstract}

Keywords: Vipassana, Ajarn Man, Buddhism, Thailand, forest traditions

\section{Introduction}

In primitive societies, when humans were faced with natural obstacles that caused feelings of fear and worry, they sought supernatural mental solutions to combat their anxiety. This supernaturalism evolved into animism (Kamdee, 2002). Primitive people would surrender to the supernatural powers by bowing, prostrating themselves on the ground and performing various ceremonies. These practices became culture and customs, developing into belief in God (Dokbua, 2006) and related belief sets (Frazer, 1964). Over time these beliefs became religions (Kinch, 1972), guiding society from birth to death (Van Baal, 1971).

Buddhism as a religion stems from the principles of the Brahman religion and based on the middle way taught by Siddhārtha Gautama of Kapilavastu. Central to the doctrine of the Gautama Buddha were the four noble truths: dukkha, the origin of dukkha, the end of dukkha, the path leading to the end of dukkha. The enlightenment of Siddhārtha Gautama is celebrated by the Thai people on Wisakha Bucha Day, or Vesak, and his teachings are focused on the threefold training of higher virtue, higher mind and higher wisdom (Kamdee, 2002).

After the death of the Gautama Buddha, Buddhist followers became divided in their opinions and philosophies, causing the development of different Buddhist schools, the two largest of which are Theravada and Mahayana. Theravada is practiced mainly in Sri Lanka, Myanmar, Thailand, Laos and Cambodia and emphasizes practice of the original teachings of the Lord Buddha with no adaptation or changes. Conversely, Mahayana allows for the adaptation of Buddhist principles to fit the customs and culture of a geographic area. This is primarily followed in China, Bhutan, Tibet, Sikkim, Mongolia, Japan and Vietnam (Kamdee, 2002).

The most important of the four historical Buddhist councils was the third, held during the reign of Emperor Ashoka the Great circa 247BCE. As a direct consequence of the council, emissaries were sent out to spread the Buddhist teachings. Of the emissaries, Pra Sona and Pra Uttra were sent to the Suwannaphum region, modern-day Nakhon Pathom. The lasting significance of Emperor Ashoka's third Buddhist council for Thailand thus lies in the establishment of a connection between Buddhist India and greater Asia and the proselytism of Buddhism (Payuttho, 1997). There were three subsequent waves of development or periods of Buddhism that have led to the current situation of two main orders of Buddhist monks in Thailand.

Dhammayuttika Nikaya is the smaller of the two orders and was formed by Prince Mongkut in 1833. Between 
King Nangklao (Rama III) and Mongkut (Rama IV), superstition and ill-disciplined practices of Buddhist monks across Thailand were eradicated and a more orthodox, conservative and ascetic religious tradition based more closely on the Pali canon was followed. These traits spread first throughout Bangkok before being transmitted across Thailand. The centre in the Northeast was at Wat Supattanaram Worawihan, a temple in Ubon Ratchatani Province (Kawkaew, 1991). Phra Ajahn Sao Kantasilo Mahathera, an abbot in Ubon Ratchatani, was the main authority for splitting the focus of Dhammayuttika Nikaya into two fields, the Buddhist sutra and vipassana. The most influential student of Phra Ajarn Sao Kantasilo Mahathera was Phrassong Saiphra Ajarn Man Phurithatto. Ajarn Man, as he was commonly known, focused on the vipassana field and spent his time meditating in forests and caves because they were places of peace and ideal for concentration (Ketsing, 1972).

The forest monks following in the footsteps of Ajarn Man dedicated their time to finding enlightenment in places of natural peace by means of meditation. Forest monks require personality characteristics of austerity and discipline. Their role is to correct the evil desires in their hearts and attain spiritual fulfillment. This is achieved by inner concentration rather than observation of others. This has caused great admiration and respect for forest monks among modern Buddhists who live in the fast-paced world of communication and technology. However, the undeniable restraint required has resulted in lapses by the forest monk community (Pajaroen, 2010).

There have been a number of studies of the Thai Buddhist forest traditions but none with the specific topic of this investigation. For this reason, the research team aim to study the Thai forest tradition of Phrassong Saiphra Ajarn Man Phurithatto with a focus on vipassana, or meditation. The hope is to discover how Phrassong Saiphra Ajarn Man Phurithatto was able to maintain his discipline and concentration and the methods he used to achieve spiritual enlightenment and successful transmission of his beliefs.

\section{The Concepts, Practices and Teachings of Phrassong Saiphra Ajarn Man Phurithatto}

The essence of the concepts, practices and teachings of Phrassong Saiphra Ajarn Man Phurithatto are as follows.

\subsection{Conduct}

The maintenance of strict religious discipline is a vital foundation to mental training and karmasthana (spiritual contemplation). The progress and bhavana of physical consciousness is assured by the continuous consideration of five areas: head hair, body hair, fingernails, teeth and skin. Monks must also observe thirteen special practices:

"Refuse-rag-wearer's Practice (pamsukulik'anga) - wearing robes made up from discarded or soiled cloth and not accepting and wearing ready-made robes offered by householders; Triple-robe-wearer's Practice (tecivarik'anga) - Having and wearing only three robes and not having additional allowable robes; Alms-food-eater's Practice (pindapatik'anga) - eating only food collected on pindapata or the alms round while not accepting food in the vihara or offered by invitation in a layman's house; House-to-house-seeker's Practice (sapadanik'anga) - not omitting any house while going for alms; One-sessioner's practice (ekasanik'anga) - eating one meal a day and refusing other food offered before midday; Bowl-food-eater's Practice (pattapindik'anga) - eating food from his bowl in which it is mixed together rather than from plates and dishes; Later-food-refuser's Practice (khalu-paccha-bhattik'anga) - not taking any more food after one has shown that one is satisfied, even though lay-people wish to offer more; Forest-dweller's Practice (araññik'anga) - not dwelling in a town or village but living secluded, away from all kinds of distractions; Tree-root-dweller's Practice (rukkhamulik'anga) - living under a tree without the shelter of a roof; Open-air-dweller's Practice (abbhokasik'anga) refusing a roof and a tree-root, the practice may be undertaken sheltered by a tent of robes; Charnel-ground-dweller's Practice (susanik'anga) - living in or nearby a charnel-field, graveyard or cremation ground; Any-bed-user's Practice (yatha-santhatik'anga) - being satisfied with any dwelling allotted as a sleeping place; Sitter's Practice (nesajjik'anga) - living in the three postures of walking, standing and sitting and never lying down.” (Wikipedia)

For the traditions of Phrassong Saiphra Ajarn Man Phurithatto, specific emphasis is placed on tecivarik'anga, rukkhamulik'anga, pindapatik'anga, pattapindik'anga, ekasanik'anga, araññik'anga, khalu-paccha-bhattik'anga and pamsukulik'anga. Monks must observe proper behavior towards teachers and complete walking meditation as well as sitting meditation. Forest monks must live in places of peace, such as forests, mountains and caves and should be frugal in their use of material possessions. Personal and private prayer must be observed daily and the monks must not reside in the same place during Buddhist lent.

\subsection{Methods of Practice}

All practices must be planned and systematic to create confidence in religious procedures. Incantations, or phuttho 
must be uttered with appropriate mindfulness and control of breathing. The phut is mentally recited on the inhalation of breath and the tho on exhalation. In defining breathing patterns, five body areas are considered important: the nose, the forehead, the crown of the head, the brain and the chest. Expressions of feeling must all come from the mind and the mind must be placed in a state of positive emotion. No mood should be permanent (Ploychum, 2006).

\section{Strategy, Discipline and Tactics of Vipassana According to Phrassong Saiphra Ajarn Man Phurithatto}

Ajarn Man identified the precepts as the foundation for all monks. The precepts were also considered by Ajarn Man as motivation for concentration (Tawaro, 2012). Monks practicing meditation must truly desire purity and commit themselves to the endeavor. As a result, Ajarn Man insisted that training of monks was more important than educating the laity because if one monk were fully trained and committed, they would then be able to instill confidence in and pass knowledge to the population (Ploychum, 2006). The difference between Ajarn Man and many modern monks is the genuine character required to implement these practices with the necessary levels of discipline. With a lack of discipline, education and knowledge suffers and monks are neither able to perform their duties completely nor pass on required understanding to their students (Yansampanno, 2006). The development of able teachers is thus vital to protecting Ajarn Man's philosophy because they hold the keys to fostering the correct personal characteristics in the new generations of believers (Ploychum, 2006). Consequently, forest monks must frequently seek teachers to continually develop their understanding, education and mentality, rather than spending their entire time in solitude (Ministry of Education, 2000).

In order to achieve appropriate standards of discipline, forest monks must concentrate on their own hearts and not the hearts of others. Ajarn Man taught that there are two types of people practicing Buddhist meditation, those with no education and those with education. Educated people will have been properly taught the skill of Anapanasati, or the mindfulness of breathing. While meditating it is important not to consider oneself sitting in a holy place but to think of the forest and surrounding peace. This will allow for mental clarity (Ploychum, 2006). This mental clarity will help with all actions and is what separates humans and primates, the full awareness of the consequences of an action (Yansampanno, 1997).

At first, the mind and faith of the meditator will be disturbed by evil desires and thoughts. These may lead to anxiety and worry. Through experience and realization of the sinfulness of the evil thoughts, meditation will become successful. So that the mind and soul are on the same path, the forest monks retreat to isolated and intimidating places. The absence of comfort also allows the monk to achieve enlightenment at a faster rate. Practices, such as fasting, are not intended to spite the body but to suffocate sinfulness (Ploychum, 2006).

If distractions are common during meditation, they may be overcome through experience, patience, realization and determination. If the meditator tries to suppress stray thoughts, they will reappear more frequently. Attempts to control the mind will lead to further struggle. Instead the mind must be trained. The meditator must not be impatient or demanding of their own mind; it will be at peace in its own time. In this way, the desire for spiritual peace is itself an evil and sinful action that contradicts the purpose of the meditation. If the mind is not at peace, monks are encouraged to exercise forbearance and patience (Phraratchasangworayan, 2000).

The meditator goes through three stages of concentration. The first is short, the second is longer and the third is the point at which jhäna is attained. Jhäna is the point at which the mind detaches. At first, it is important to continue as though the mind and body are still one to prevent shock. There is a danger of fear during the state of jhanna; fear for the mind when the body has gone. The only remedy for this fear is frequent practice of vipassana. Once in the final stage of concentration, no commands may be sent to the mind. The meditator must thus wait until the mind returns to the body (Phraratchasangworayan, 2000). The meditator will unavoidably meet a number of different circumstances during the third stage of consciousness, including feelings of lightness, heaviness and dizziness. These are overcome through experience. If performed correctly, meditation can lead to right concentration, the eighth factor of the noble eightfold path, the fourth of the Lord Buddha's noble truths.

\section{The Characteristics Required of Potential Monks in Phrassong Saiphra Ajarn Man Phurithatto's Field of Vipassana}

There are eleven characteristics required of potential monks in Phrassong Saiphra Ajarn Man Phurithatto's field of vipassana. These are as follows:

- They must have faith in Buddhism and believe in the vipassana principles of Phrassong Saiphra Ajarn Man Phurithatto.

- They must be true and free from sin because it is difficult for unreliable and untrustworthy individuals to be successful forest monks. 
- They must be humble, modest and well-mannered. Monks under the tutelage of Phrassong Saiphra Ajarn Man Phurithatto must teach well and respect their elders at the same time. They must be committed to their daily tasks and foster harmony in their order, especially between junior and senior monks.

- They must be thrifty, resourceful, considerate, helpful and generous. They must be orderly but, at the same time, pity all animals who are less fortunate.

- They must have extensive knowledge of Buddhist doctrine and practice. They should also be able to recite the Prātimokșa, a list of rules for Buddhist monks, and ideally be experts in the Bihar language, able to learn scripts, observe precepts and possess the 'four immeasurables'.

- They must not scrutinize the faults of others and must concentrate on themselves.

- They must aim to advance their moral consciousness to the highest achievable level.

- They must not be lazy and must be tolerant, patient in the face of difficulty. They must elevate the Buddhist religion and seek to continue its teachings.

- They must be in continuous harmony with their order.

- They must care for and maintain the property and grounds of their order.

- They must be able to cut, sew and embroider cloth with their own hands.

\section{Ways to Overcome Limitations and Restrictions of Monks in Phrassong Saiphra Ajarn Man Phurithatto's Field of Vipassana}

Modern Thai society has changed since the time of Phrassong Saiphra Ajarn Man Phurithatto and monks have had to adapt accordingly. There are three areas of restriction.

\subsection{Surrounding Environment}

The state of local forests has changed from the time of Phrassong Saiphra Ajarn Man Phurithatto. There has been much deforestation and the governments have not controlled or restricted this enough to prevent the loss of habitat. By way of solution, more laws should be created to restrict deforestation and more authority should be given to the monks to protect the forests. Additionally, local community programs could be increased to replant trees and educate local residents into the value of the forests. This must be emphasized in conjunction with corporate social responsibility. The stronghold of Phrassong Saiphra Ajarn Man Phurithatto's teachings is in Northeastern Thailand. For this reason, initiatives must begin there and gradually spread across the country.

\subsection{Mentality}

Given the reverence held by the people for the forest monks, it is especially important for the monks to maintain an appropriate mentality at all times. They are often unable to escape the scrutiny of Buddhists worldwide. With this comes the threat of dilution of Phrassong Saiphra Ajarn Man Phurithatto's teachings. When Ajarn Man formulated his ideas, Thai society was a different place and there was little danger of external influence altering his beliefs. Now, with rapid globalization and the transmission of international Buddhist ideas, there is a greater chance of the forest monks drifting from the original lessons. For this reasons, it is increasingly important tho ensure that forest monks undergo strict and thorough training under the same conditions as those of Ajarn Man.

The modern way is for young men to ordain as monks for temporary periods before returning to a layperson's life. If the forest traditions are to be maintained, especially the process of vipassana, monks must be in service for at least three to five years. This will protect the integrity of the position. There is one obvious disadvantage to making this change, which is the reduction of eligible forest monks. Despite the numbers of trainee monks who would be lost to the order, the research team considers the potential benefit of these restrictions to far outweigh the negative impact. Therefore, the research team recommends that all forest monks must commit to a minimum service period of three to five years and undergo a character examination before being deemed suitable for their positions.

\subsection{Administration}

The vipassana of Phrassong Saiphra Ajarn Man Phurithatto is hindered by uncoordinated administration. The various related government institutions and ministries should take an active role in supporting the doctrine of Phrassong Saiphra Ajarn Man Phurithatto, especially considering the $94 \%$ of the population who consider Buddhism as its religion. If Buddhism is in any way weak, the nation will be affected, such is the link between the two. It is therefore in the national interest to protect Buddhist values and principles. This can be achieved in a variety of ways, including dissemination of teachings, mode of practices, strategies and policies on the basis of threefold training to encourage the population to adhere to higher virtue, higher mind and higher wisdom. At the 
moment though, dissemination of ideas is not done correctly or efficiently and there are many elements of modern Thai society that lack meaningfulness. This third obstacle directly effects the aforementioned first and second hurdles and can thus be considered as the most important.

\section{Suggestions}

\subsection{Suggestions for Development}

The results of this research should be used to create a training manual for forest monks, which should be published and distributed by Mahamakut Buddhist University. The information should be easy to understand and available for the general public. It could even take the form of a video, movie or cartoon. A method should be outlined to combat the three problems identified by this research. The Ministry of Natural Resources and Environment must take a more aggressive stance in protecting the forests of Thailand that the monks use as worship grounds. In addition, related government institutions must take a more active role in maintaingin and increasing the quality of the vipassana of Phrassong Saiphra Ajarn Man Phurithatto.

\subsection{Suggestions for Further Research}

Further study should consider the following five topics:

- Future leaders of vipassana

- The differences and success of vipassana in the past and present

- The factors for success and failure of vipassana monks

- The problems and obstacles to allowing forest monks the authority to control local forests

- The religious places of Thai forest monks

\section{References}

Dokbua, F. (2006). Comparative religion [in Thai]. Bangkok: Sopon Printing.

Frazer, J. (1993). The golden bough. London: Wordsworth.

Kamdee, D. (2002). Religious studies [in Thai]. Bangkok: Kasetsart University.

Kawkaew, P. (1991). The birth and spread of Dhammayuttika Nikaya in Northeastern Thailand [in Thai]. PhD thesis, Chulalongkorn University, Bangkok.

Ketsing, A. (1978). The life of forest monks [in Thai]. Ratchaburi: Suttisarn Printing.

Kinch, J. (1972). Introductory sociology. California: Individual Learning System.

Mahamakut Buddhist University. (2004). History of the Dhammayuttika order [in Thai]. Nakhon Pathom: Mahamakut Buddhist University.

Ministry of Education. (2000). Watering the lotus [in Thai]. Bangkok: Chuanpim.

Pajaroen. W. (2010). Expected roles and the reality of Thai monks that have an effect on the religious faith of the Buddhist community [in Thai]. PhD Thesis, Pathum Thani University, Pathum Thani.

Payuttho, P. (1997). Buddhism in Asia [in Thai]. Bangkok: Thammasapa.

Phraratchasangworayan. (2000). Training the mind [in Thai]. Bangkok: Mahamakut Buddhist University.

Ploychum, S. (2006). Ajarn Man Phurithatto's institution of vipassana [in Thai]. Bangkok: Chulalongkorn University.

Tawaro, J. (2012). 227 practices of Phrawinai [in Thai]. Bangkok: Siam Art Packaging and Printing.

Van Baal, J. (1971). Symbols for communication. Amsterdam: The Royal Van Goreum.

Wikipedia. Dhutanga. Retrieved May 27, 2014, from http://en.wikipedia.org/wiki/Dhutanga

Yansampanno, B. (1997). The basis of the heart [in Thai]. Bangkok: Chuanpim.

Yansampanno, B. (2006). Biography of Ajarn Man Phurithatto [in Thai]. Bangkok: S.P.N.

\section{Copyrights}

Copyright for this article is retained by the author(s), with first publication rights granted to the journal.

This is an open-access article distributed under the terms and conditions of the Creative Commons Attribution license (http://creativecommons.org/licenses/by/3.0/). 